\title{
INITIAL DEVELOPMENT OF CLADODE GIANT SWEET CLONE AS A FUNCTION OF WATER AND SALINE STRESS
}

\author{
Leandro Ricardo Rodrigues de LUCENA ${ }^{1}$ \\ Álefe Chagas de Lima COSTA ${ }^{1}$ \\ Antonio Dennys Melo de OLIVEIRA ${ }^{1}$ \\ Maurício Luiz de Mello Vieira LEITE ${ }^{1}$
}

- ABSTRACT: Forage plants are considered one of the main factors for the development of livestock worldwide, for presenting high potential for phytomass production, drought tolerance, high energy value, large water reserve and easy propagation. Forage cactus stands out for its tolerance to water deficit. Aimed to evaluate the initial performance of the morphometric characteristics of Giant Sweet clone ( $N$. cochenillifera) submitted to water and saline stresses using response surface analysis. Design used was completely randomized in a $4 \mathrm{x} 4$ factorial scheme, composed of four levels of water replacement, based on crop evapotranspiration (ETc): (25\%.ETc, 50\%.ETc, $75 \%$.ETc and 100\%.ETc) and four levels of water salinity $(0,2,4$ and 8 $\mathrm{dS} / \mathrm{m}$ ), with four repetitions totalling 64 experimental units. The following morphometric characteristics were evaluated: plant height, length, width, thickness, number of cladodes and area of cladodes. Eight evaluations were realized during the experimental period. Response surface analysis was used to evaluate the morphometric characteristics of the cladodes. Best water levels were between 55\%.ETc and 65\%.ETc and saline levels between 3.5 and $5 \mathrm{dS} / \mathrm{m}$, maximizing the morphometric characteristics of Giant Sweet clone.

- KEYWORDS: Morphometric characteristics; Nopalea cochenillifera; response surface.

\section{Introduction}

Forage plants are considered one of the main factors for the development of livestock worldwide, for presenting high potential for phytomass production, drought tolerance, high energy value, large water reserve and easy propagation (PEREIRA et al., 2018). Semi-arid regions have low availability and quality of forages throughout the year, due to long periods of drought (LUCENA et al., 2016).

Water deficit is quite common in semiarid regions, causing changes in the anatomy, physiology and biochemistry of plants (ARAÚJO et al., 2010), which can affect all stages of development (BALARDIN et al., 2011), up to growth and productivity (BILIBIO et al., 2010). Knowledge of the performance of forage plants under water stress conditions is of great value to assist in understanding the effect of the "dry" period on forage

\footnotetext{
${ }^{1}$ Universidade Federal Rural de Pernambuco - UFRPE, Campus Serra Talhada, Av. Gregório Ferraz Nogueira, CEP: 56909-535, Serra Talhada, PE, Brasil. E-mail: leandroricardo_est@yahoo.com.br; alefechagas@outlook.com; dennysmelo15@gmail.com; nopalea21@yahoo.com.br
} 
production, thus allowing the use of viable management practices to improve cultivation during this period (ARAÚJO JUNIOR et al., 2019).

Forage plants with the influence of water stress suffer with salt stress, since the waters of the semiarid regions have high concentrations of salts (SILVA et al., 2018). Accumulation of salts in the soil promotes an unfavourable environment for plant development, because it negatively alters crop growth reducing the productivity of forage plants in agricultural areas (MUNNS and TESTER, 2008). Saline stress also promotes stomatal closure that induces a reduction in $\mathrm{CO}_{2}$ assimilation and consequently less plant growth and less biomass accumulation (SILVA et al., 2018).

In the face of this scenario, the forage cactus stands out, as it has tolerance to water deficit (FREIRE et al., 2018; LEITE et al., 2014) with emphasis on the specie Nopalea cochenillifera Salm-Dyck for being resistant to Dactylopius opuntiae. All these aspects make it necessary to study the development and growth of forage cactus under these conditions. Knowledge of growth curves of a species provides very useful information in the cultivation and management crop, and has great biological importance, as they enable the viability cultive of a species by assessing the growth rate.

The fit of growth curves is an important tool to gain knowledge of the plant's growth and its phenological stages (LEITE et al., 2017; 2019, LUCENA et al., 2016). Growth curves generate useful information such as: adequate crop management, period of greatest plant growth, most suitable time for fertilization and pest control (MANGUEIRA et al., 2016). Among the models of growth curves, the response surface methodology (RSM) stands out. RSM is a collection of statistical techniques useful for modelling and analysis in applications where the response of interest is influenced by two or more variables, aiming optimize the response as a function of the combined effects of the variables under test (LUCENA et al., 2019a, 2019b).

Given the above, aimed to evaluate the initial performance of the morphometric characteristics of Giant Sweet clone ( $N$. cochenillifera) submitted to water and saline stresses using response surface analysis.

\section{Material and methods}

The research was carried in Federal Rural University of Pernambuco, Campus of Serra Talhada (UFRPE/UAST), Serra Talhada, Pernambuco, Brazil (elevation: $429 \mathrm{~m}$, latitude: $7^{\circ} 56^{\prime} 15^{\prime \prime} \mathrm{S}$ and longitude: $38^{\circ} 18^{\prime} 45^{\prime \prime} \mathrm{E}$ ) (Figure 1). According to Koppen, the climate condition is BSwh', denominated Semiarid, hot and dry, with rainy season during the summer (LEITE et al., 2019) with average annual rainfall of $632.2 \mathrm{~mm} / \mathrm{year}$ and average air temperatures of $26^{\circ} \mathrm{C}$ and average relative humidity 60\% (LUCENA et al., 2018). 


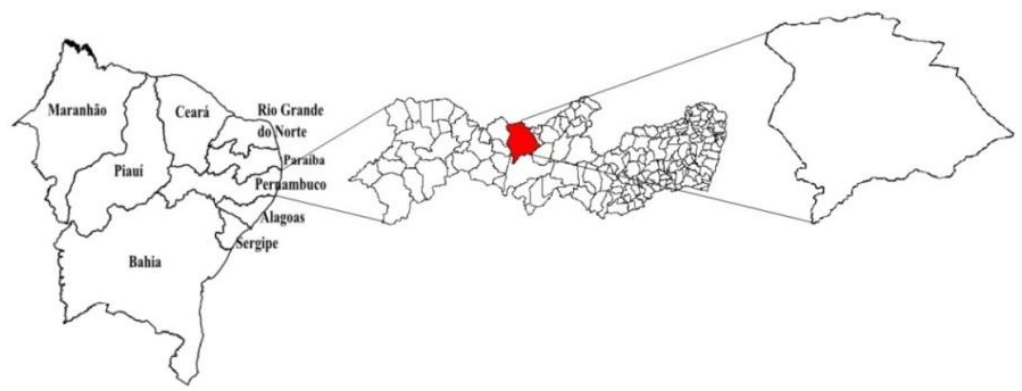

Figure 1 - Location of the study area.

Soil used in the experiment (Typical Haplic Cambisol Ta Eutrophic) was collected at a depth of $0-20 \mathrm{~cm}$. After analysis was characterized by the following chemical attributes: $\mathrm{pH}$ (water) $=7,20 ; \mathrm{P}$ (Mehlich I extractor) $=40 \mathrm{mg} \mathrm{dm}{ }^{-3} ; \mathrm{K}^{+}=0,45 ; \mathrm{Ca}^{2+}=5,3 ; \mathrm{Mg}^{2+}=1,10$; $\mathrm{Al}^{3+}=0,0 \mathrm{cmol}_{\mathrm{c}} \mathrm{dm}^{-3}$ (ALMEIDA et al., 2017).

Design used was completely randomized in a $4 \times 4$ factorial scheme, consisting of four levels of water replacement, based on crop evapotranspiration (ETc) (25\%.ETc, $50 \%$.ETc, $75 \%$.ETc and 100\%.ETc) and four levels of water salinity, with four repetitions, totalling 64 experimental units. To calculate the approximate field capacity of the soil, the initial mass of the pot + soil + sand set of all pots was determined, after added water until saturation condition.

To avoid water loss through evaporation, the pots were covered with plastic wrap, and placed on bricks so that they can only lose water through drainage over a 24-hour period, time needed to reach constant mass. Due to the difference in mass between the pots with soil in the field capacity and with dry soil, it was possible to determine the maximum quantity of water that the soil of the pots will retain. Subsequently, blades were calculated for predetermined available water conditions.

For the salt deficit, four levels of irrigation water salinity were used, resulting from different electrical conductivities (0, 2, 4 and $8 \mathrm{dS} / \mathrm{m}$ ) (LUCENA et al., 2019a). To obtain saline levels, sodium chloride $(\mathrm{NaCl})$ salts were added to distilled water. In the laboratory, the levels of 2, 4 and $8 \mathrm{dS} / \mathrm{m}$ were obtained through the concentrations of $(\mathrm{NaCl})$ salts corresponding to $1.16,2.32$ and $4.64 \mathrm{~g} / \mathrm{L}$, respectively (LUCENA et al., 2019a).

Forage cactus were planted in pots with a capacity of $14.41 \mathrm{dm}^{3}$, in each pot a cladode of forage cactus Giant Sweet clone (N. cochenillifera) was placed with $15.0 \mathrm{~kg}$ of soil. Pots were arranged at a spacing of $0.3 \mathrm{~m} \times 0.3 \mathrm{~m}$ and placed on brick blocks to avoid direct contact with soil and facilitate the collection of drained water. Before planting, the treatment that each pot received was drawn. The draw was carried out computationally using the R-project software, where each pot received a number from 1 to 64 . Numbers 1 to 4 were assigned to treatment 1,5 to 8 for treatment $2, \ldots, 57$ to 60 for treatment 15 , and 61 to 64 for treatment 16 . Treatments were the combination of the irrigation blade with the level of salinity used as described in Table 1. 
Table 1 - Description of treatments used

\begin{tabular}{ccccc}
\hline Water level & \multicolumn{4}{c}{ Water salinity level $(\mathrm{dS} / \mathrm{m})$} \\
\cline { 2 - 5 }$(\%$ ETc $)$ & 0 & 2 & 4 & 8 \\
\hline $25 \%$ & $\mathrm{~T} 1$ & $\mathrm{~T} 2$ & $\mathrm{~T} 3$ & $\mathrm{~T} 4$ \\
$50 \%$ & $\mathrm{~T} 5$ & T6 & T7 & T8 \\
$75 \%$ & $\mathrm{~T} 9$ & $\mathrm{~T} 10$ & $\mathrm{~T} 11$ & $\mathrm{~T} 12$ \\
$100 \%$ & $\mathrm{~T} 13$ & $\mathrm{~T} 14$ & $\mathrm{~T} 15$ & $\mathrm{~T} 16$ \\
\hline
\end{tabular}

$\mathrm{ETc}=$ crop evapotranspiration.

The result of the draw for allocation of treatments in the referred sample units was as shown in Figure 2.

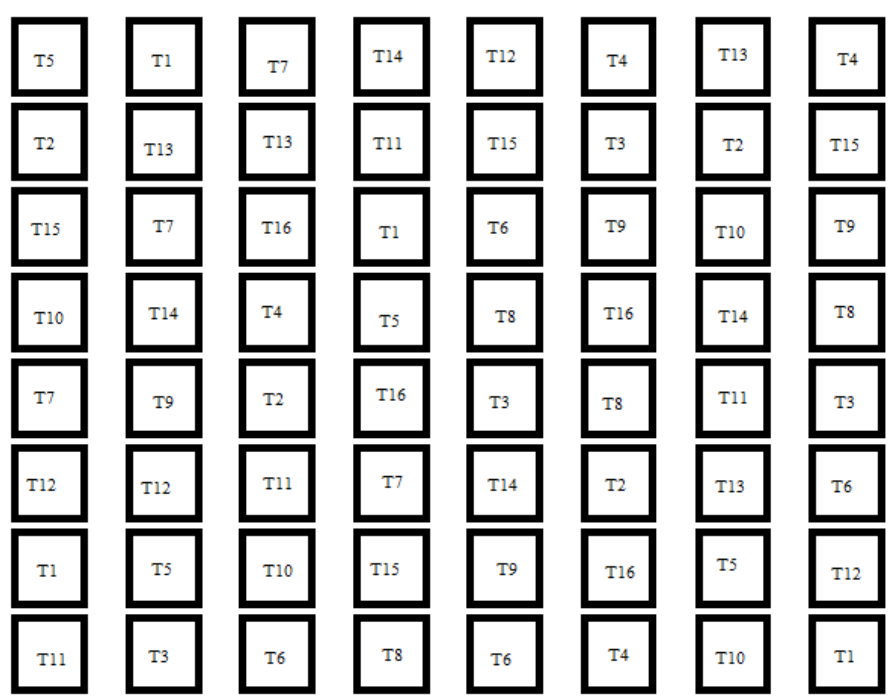

Figure 2 - Sample scheme.

The following morphometric characteristics were evaluated: plant height, cladode length, width, thickness, number of cladodes and cladode area. Cladode area was estimated by the product of the length by the width of the cladodes according to the methodology of Lucena et al. (2019c) and Leite et al. (2020). The evaluations were carried out every 15 days, totalling eight evaluations during the experimental period. The values of the morphometric variables were recorded in Excel spreadsheets and analyses carried out using R (R CORE TEAM, 2020).

Plant height (PH), cladode length (L), cladode width (W), cladode thickness (T) and cladode area (A) were evaluated using the response surface analysis methodology. Response surface was defined as the geometric representation obtained from the response as a function of two quantitative factors (water and salt levels). Response surface is defined by equation (1)

$$
Y=f\left(X_{1}, X_{2}\right)+\varepsilon,
$$


where, $Y$ is the response (plant height, cladode length, cladode width, cladode thickness, and cladode area); $X_{1}$ and $X_{2}$ are the factors (water and saline level) and $\varepsilon$ is the random error. The response expected by equation (2)

$$
E(Y)=f\left(X_{1}, X_{2}\right)=\eta
$$

and, is denominated response surface (LUCENA et al., 2019a, 2019b). equation (3)

In the present study the rresponse surface function $f\left(X_{1}, X_{2}\right)$ is defined by

$$
Y=f\left(X_{1}, X_{2}\right)+\varepsilon=\beta_{0}+\beta_{1} X_{1}+\beta_{2} X_{2}+\beta_{3} X_{1} X_{2}+\beta_{4} X_{1}^{2}+\beta_{5} X_{2}^{2}+\varepsilon,
$$

where, $\beta_{0}, \beta_{1}, \beta_{2}, \beta_{3}, \beta_{4}$ and $\beta_{5}$ are the unknown parameters and $\varepsilon$ random error follows normal distribution of mean 0 and constant variance $\sigma^{2}$. The model above can be written in the matrix form described in equation (4)

$$
Y=\beta X+\varepsilon,
$$

where, $Y^{\prime}=\left[Y_{1}, Y_{2}, \ldots, Y_{N}\right], X$ is the matrix $N \times p ; p=6 ; \beta$ is a vector $p \times 1$ of unknown parameters and $\varepsilon^{\prime}=\left[\varepsilon_{1}, \varepsilon_{2}, \ldots, \varepsilon_{N}\right]$. Using the least squares estimator, parameter estimates are expressed by equation (5)

$$
\hat{\beta}=\left(X^{\prime} X\right)^{-1} X^{\prime} Y .
$$

In order to find the optimal levels of water level (H) and salinity (S) that maximize plant height, length, width, thickness and cladode area of $N$. cochenillifera Giant Sweet clone we use the stationary point. This point is calculated solve the following equation system defined in equation (6) and (7) given by

$$
\frac{\partial \widehat{\mathrm{Y}}}{\partial \mathrm{X}_{1}}=\hat{\beta}_{1}+2 \hat{\beta}_{3} \mathrm{X}_{1}+\hat{\beta}_{5} \mathrm{X}_{2}=0
$$

and,

$$
\frac{\partial \widehat{\mathrm{Y}}}{\partial \mathrm{X}_{2}}=\hat{\beta}_{2}+2 \hat{\beta}_{4} \mathrm{X}_{2}+\hat{\beta}_{5} \mathrm{X}_{1}=0
$$

To test the significance of the adjusted model, a variance analysis procedure (ANOVA) is performed. Considering the system of normal equations defined in equation (8) given by

$$
\left(X^{\prime} X\right) \hat{\beta}=X^{\prime} Y
$$


Sum of total squares (SST), regression (SSReg) and residuals $(S S R)$ can be obtained by the following expressions:

$$
S S T=Y^{\prime} Y-N \bar{Y}^{2} ; S S R=Y^{\prime} Y-\hat{\beta}^{\prime} X^{\prime} Y ; \operatorname{SSReg}=\hat{\beta}^{\prime} X^{\prime} Y-N \bar{Y}^{2}
$$

where, $\bar{Y}=\frac{\sum_{i=1}^{N} Y_{i}}{N}$.

To evaluate the adequacy of the model, was used the determination coefficient of the adjusted model $R_{a j u}^{2}$, defined by equation (9):

$$
\mathrm{R}_{\mathrm{aju}}^{2}=\mathrm{R}^{2}-\frac{p-1}{N-p}\left(1-\mathrm{R}^{2}\right)
$$

where, $0 \leq R_{a j u}^{2} \leq 1$ and $R^{2}=\frac{\text { SSReg }}{\text { SST }}$.

\section{Results and discussion}

At 150 days after planting, plants submitted to\% ETc between 50 and 75 and salinity levels between 2 and $4 \mathrm{dS} / \mathrm{m}$ showed the best results for the morphometric characteristics of Giant Sweet clone (N. cochenillifera) (Table 2).

Similar results were observed by Gajender et al. (2014) when they verified that the salinity in the irrigation water negatively affects the morphometric characteristics of Opuntia fícus-indica. Salazar and Véliz (2007) verified that the increase in the level of salinity reduces the volume of cladodes of the $O$. ficus-indica, and consequently reduces their linear dimensions (length, width and thickness). Amador et al. (2001) verified that the number, length and width of cladodes are reduced as the level of salinity increases in the irrigation water in cladodes of the $O$. ficus-indica.

Queiroz et al. (2015) verified in O. stricta that its plant height, length, width, thickness and number of cladodes are affected with the increase in the percentage of reference evapotranspiration. Situation found in the present study, thus allowing a water deficit in the soil, which compromised the vegetative development in the plant. 
Table 2 - Average and standard deviation of the Giant Sweet clone (N. cochenillifera) morphometric characteristics as a function of water $(\mathrm{ETc}=$ crop evapotranspiration) and salt stress at 150 days after planting

\begin{tabular}{|c|c|c|c|c|}
\hline \multirow{2}{*}{$\begin{array}{c}\text { Water level } \\
\text { (\% ETc) }\end{array}$} & \multicolumn{4}{|c|}{ Water salinity level (dS/m) } \\
\hline & 0 & 2 & 4 & 8 \\
\hline & \multicolumn{4}{|c|}{ Cladode number (und.) } \\
\hline $25 \%$ & $1.5 \pm 1.0$ & $2.3 \pm 0.5$ & $1.8 \pm 0.4$ & $1.3 \pm 0.6$ \\
\hline $50 \%$ & $1.8 \pm 0.5$ & $1.5 \pm 0.6$ & $1.8 \pm 0.5$ & $1.8 \pm 0.9$ \\
\hline $75 \%$ & $1.8 \pm 0.5$ & $2.3 \pm 0.5$ & $1.5 \pm 0.7$ & $1.3 \pm 0.5$ \\
\hline \multirow{2}{*}{$100 \%$} & $1.3 \pm 0.5$ & $1.8 \pm 0.5$ & $2.5 \pm 0.6$ & $1.8 \pm 0.5$ \\
\hline & \multicolumn{4}{|c|}{ Plant height $(\mathrm{cm})$} \\
\hline $25 \%$ & $43.5 \pm 5.2$ & $37.6 \pm 7.7$ & $45.4 \pm 2.7$ & $40.2 \pm 3.4$ \\
\hline $50 \%$ & $42.6 \pm 7.5$ & $43.3 \pm 8.7$ & $45.0 \pm 5.7$ & $40.1 \pm 3.7$ \\
\hline $75 \%$ & $36.1 \pm 6.9$ & $39.2 \pm 6.5$ & $40.5 \pm 4.3$ & $39.8 \pm 8.9$ \\
\hline \multirow[t]{2}{*}{$100 \%$} & $43.1 \pm 6.4$ & $41.8 \pm 5.5$ & $38.9 \pm 3.4$ & $34.6 \pm 5.7$ \\
\hline & \multicolumn{4}{|c|}{ Cladode length $(\mathrm{cm})$} \\
\hline $25 \%$ & $25.4 \pm 4.8$ & $23.1 \pm 5.7$ & $26.9 \pm 3.6$ & $25.6 \pm 2.7$ \\
\hline $50 \%$ & $24.6 \pm 3.8$ & $26.8 \pm 3.8$ & $25.5 \pm 5.2$ & $21.8 \pm 2.9$ \\
\hline $75 \%$ & $22.7 \pm 2.5$ & $22.8 \pm 5.5$ & $23.9 \pm 5.2$ & $24.5 \pm 3.7$ \\
\hline \multirow[t]{2}{*}{$100 \%$} & $26.3 \pm 4.9$ & $24.6 \pm 3.5$ & $22.1 \pm 3.2$ & $22.7 \pm 4.7$ \\
\hline & \multicolumn{4}{|c|}{ Cladode width (cm) } \\
\hline $25 \%$ & $11.1 \pm 1.2$ & $9.5 \pm 0.4$ & $11.3 \pm 1.2$ & $10.9 \pm 2.1$ \\
\hline $50 \%$ & $11.3 \pm 1.3$ & $10.5 \pm 1.4$ & $10.9 \pm 2.5$ & $8.6 \pm 2.2$ \\
\hline $75 \%$ & $9.2 \pm 0.5$ & $9.3 \pm 2.0$ & $9.9 \pm 2.3$ & $11.0 \pm 1.5$ \\
\hline \multirow[t]{2}{*}{$100 \%$} & $11.9 \pm 2.4$ & $11.0 \pm 0.6$ & $9.2 \pm 0.9$ & $7.9 \pm 0.3$ \\
\hline & \multicolumn{4}{|c|}{ Cladode thickness (mm) } \\
\hline $25 \%$ & $16.5 \pm 1.2$ & $12.8 \pm 1.3$ & $15.4 \pm 1.1$ & $15.2 \pm 0.8$ \\
\hline $50 \%$ & $14.8 \pm 1.9$ & $15.4 \pm 1.2$ & $13.3 \pm 2.7$ & $13.1 \pm 1.7$ \\
\hline $75 \%$ & $14.8 \pm 0.5$ & $14.3 \pm 1.9$ & $13.8 \pm 2.2$ & $12.1 \pm 2.1$ \\
\hline \multirow[t]{2}{*}{$100 \%$} & $15.7 \pm 1.7$ & $13.1 \pm 0.8$ & $11.8 \pm 1.6$ & $12.9 \pm 2.6$ \\
\hline & \multicolumn{4}{|c|}{ Cladode area $\left(\mathrm{cm}^{2}\right)$} \\
\hline $25 \%$ & $284.7 \pm 84.2$ & $219.9 \pm 56.2$ & $307.1 \pm 69.6$ & $281.5 \pm 84.5$ \\
\hline $50 \%$ & $281.4 \pm 77.5$ & $284.8 \pm 70.9$ & $285.7 \pm 123.9$ & $183.7 \pm 31.5$ \\
\hline $75 \%$ & $207.8 \pm 28.4$ & $218.9 \pm 91.3$ & $246.1 \pm 109.3$ & $271.6 \pm 72.6$ \\
\hline $100 \%$ & $319.1 \pm 112.1$ & $271.1 \pm 54.3$ & $205.0 \pm 49.2$ & $179.2 \pm 36.9$ \\
\hline
\end{tabular}

Cladode area, plant height, cladode length and width showed quadratic behavior as a function of water and saline level as well as interaction between stresses (Table 3 and Figures 3 to 6, respectively). Freire et al. (2018) verified quadratic behavior for the Little Sweet clone $(N$. cochenillifera) cladode width, maximizing their width $(5.37 \mathrm{~cm})$ with an optimum salinity level of $2.57 \mathrm{dS} / \mathrm{m}$ with an accuracy of $54.05 \%$. In the present study, the cladode width maximized by $10.55 \mathrm{~cm}$ when used $4.44 \mathrm{dS} / \mathrm{m}$ and with accuracy of $95.2 \%$. 
Table 3 - Response surface of the morphometric characteristics of the cladodes, adequacy criteria $\left(\mathrm{R}^{2}\right)$ and optimal levels of \%ETc and water salinity

\begin{tabular}{|c|c|c|c|c|c|}
\hline $\begin{array}{l}\text { Morphometric } \\
\text { characteristics }\end{array}$ & Response surface & $\mathrm{R}^{2}$ & $\mathrm{H}_{0}$ & $\mathrm{~S}_{0}$ & $\mathrm{Y}_{0}$ \\
\hline Cladode area & $\begin{array}{l}6.514 \mathrm{H}+29.24 \mathrm{~S}-0.043 \mathrm{H}^{2}-1.45 \mathrm{~S}^{2}- \\
0.302 \mathrm{HS}\end{array}$ & 0.926 & 63.5 & 3.47 & 257.52 \\
\hline Plant height & $\begin{array}{l}1.16 \mathrm{H}+4.28 \mathrm{~S}-0.008 \mathrm{H}^{2}-0.203 \mathrm{~S}^{2}- \\
0.039 \mathrm{HS}\end{array}$ & 0.968 & 61.1 & 4.67 & 45.44 \\
\hline Cladode length & $\begin{array}{l}0.68 \mathrm{H}+2.48 \mathrm{~S}-0.005 \mathrm{H}^{2}-0.12 \mathrm{~S}^{2}- \\
0.023 \mathrm{HS}\end{array}$ & 0.962 & 56.73 & 4.9 & 25.36 \\
\hline Cladode width & $\begin{array}{l}0.28 \mathrm{H}+1.106 \mathrm{~S}-0.002 \mathrm{H}^{2}-0.053 \mathrm{~S}^{2}- \\
0.011 \mathrm{HS}\end{array}$ & 0.952 & 57.79 & 4.44 & 10.55 \\
\hline Cladode thickness & $0.3 \mathrm{H}+0.512 \mathrm{~S}-0.002 \mathrm{H}^{2}-0.009 \mathrm{HS}$ & 0.907 & 56.89 & 8.05 & 10.59 \\
\hline
\end{tabular}

Through of the response surface of cladode area verified that using the water level of $63.5 \%$.ETc and $3.47 \mathrm{dS} / \mathrm{m}$ of salinity, maximized the cladode area of the $N$. cochenillifera in $257.52 \mathrm{~cm}^{2}$ at 150 days after planting (Figure 3). Different result was reported by Queiroz et al. (2015) that using 17.5\%.ETc maximized the cladode area of the $O$. stricta in $44.84 \mathrm{~cm}$, since the specie studied by the authors has greater tolerance to water stress than the $N$. cochenillifera.
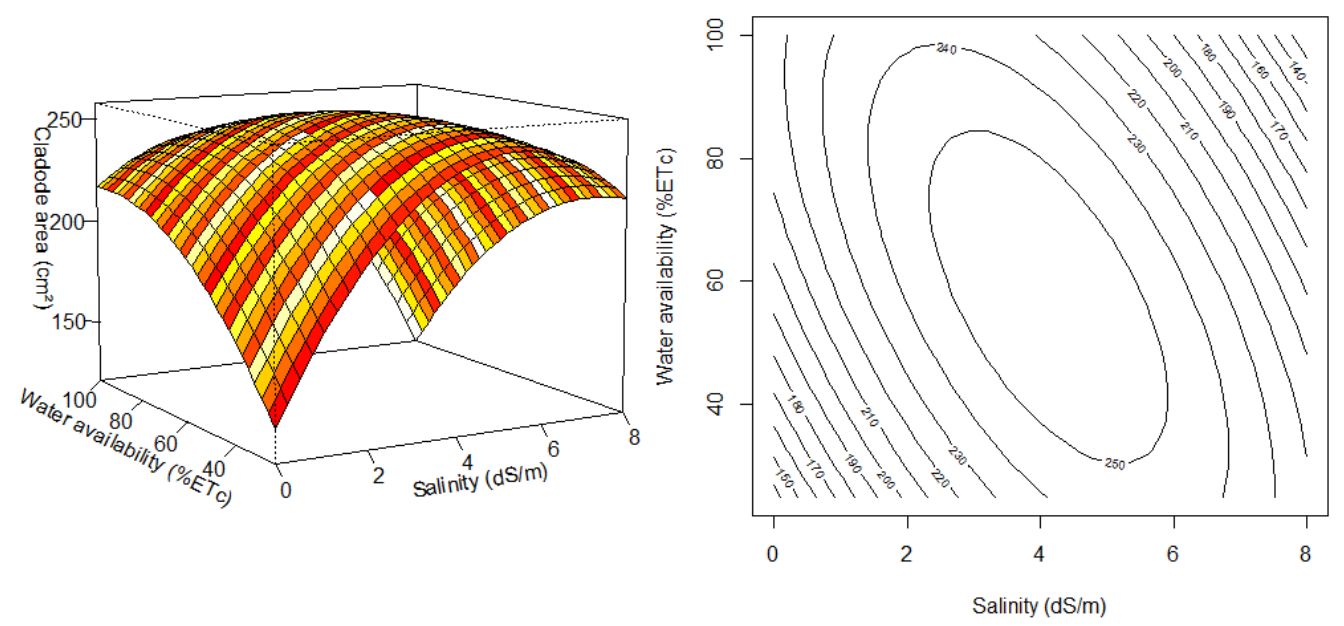

Figure 3 - Response surface of the cladode area of $N$. cochenillifera.

Plant height of $N$. cochenillifera had its maximum at $45.44 \mathrm{~cm}$ at 150 days after planting when water level of $61.1 \%$.ETc and $4.67 \mathrm{dS} / \mathrm{m}$ of salinity was used (Figure 4). 
Similar results were reported by Gajender et al. (2014) when verifying that the O. ficusindica clone supports a salinity level of up to $4 \mathrm{dS} / \mathrm{m}$ without changing the plant height.

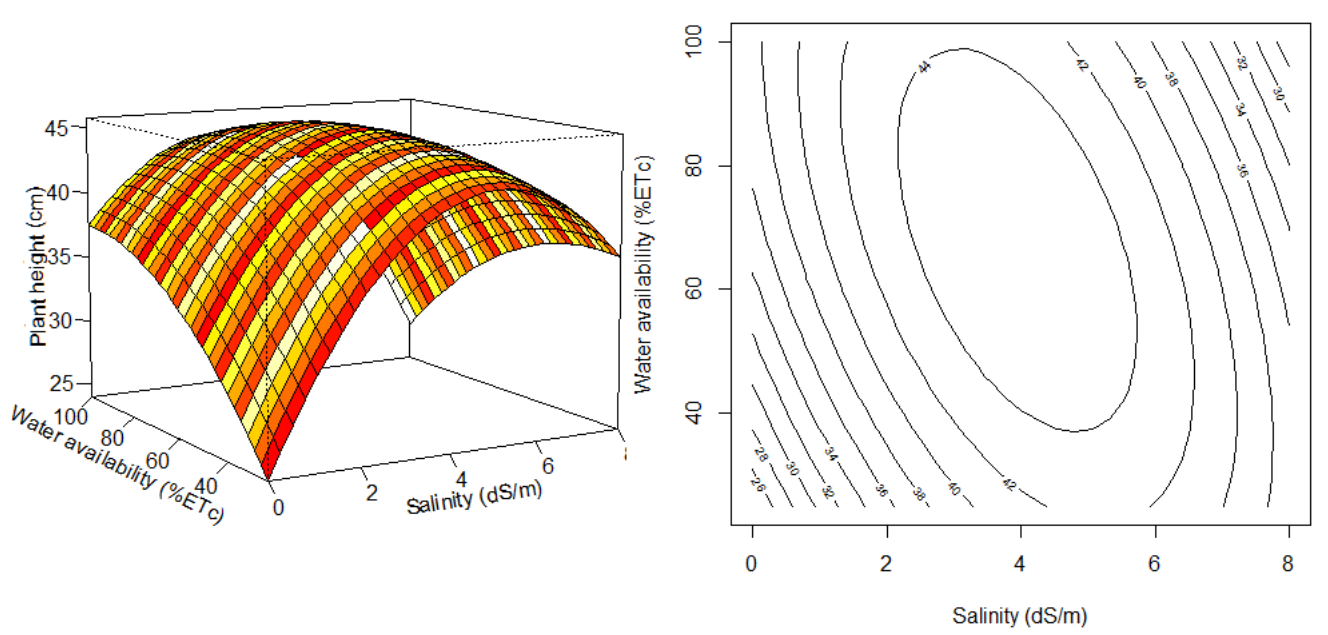

Figure 4 - Response surface of plant height of $N$. cochenillifera.

Response surface of the length of the cladodes maximized its length by $25.36 \mathrm{~cm}$ when $56.73 \%$.ETc and $4.9 \mathrm{dS} / \mathrm{m}$ were used at 150 days after planting (Figure 5).
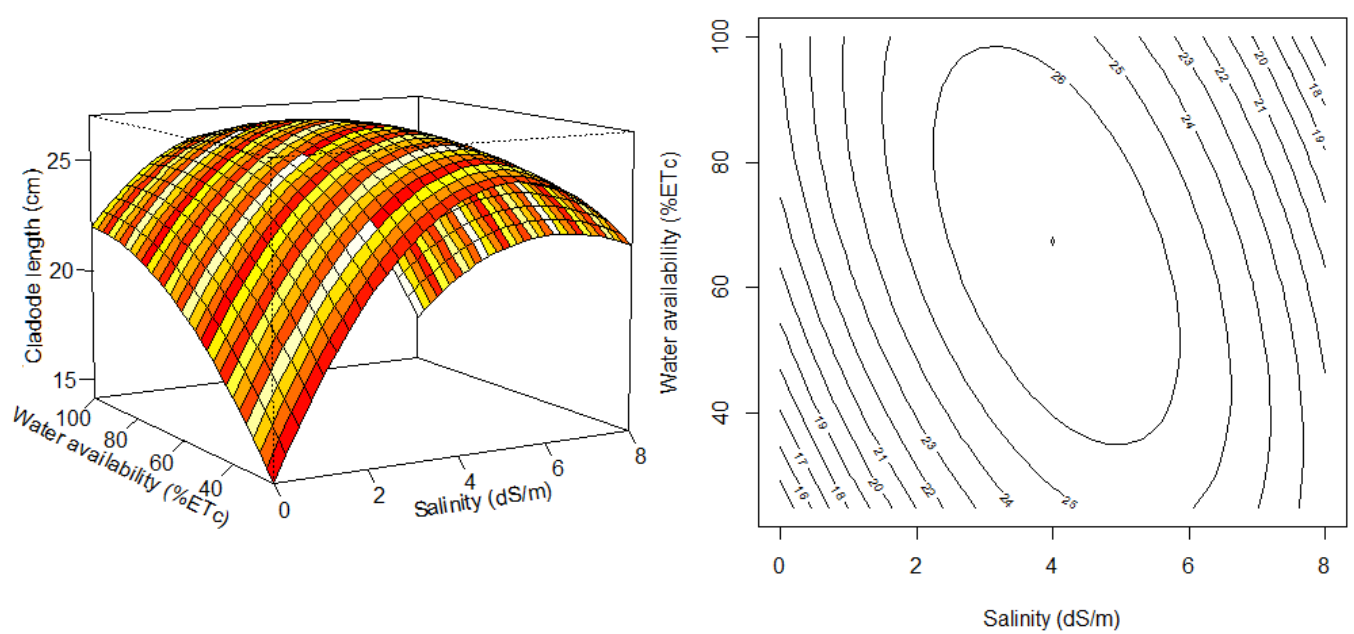

Figure 5 - Response surface of the cladode length of $N$. cochenillifera. 
Amador et al. (2018) verified in O. ficus-indica that the cladode length is affected when salinity levels above $3 \mathrm{dS} / \mathrm{m}$ are used. Queiroz et al. (2015) verified that when $0 \%$ ETc used, they maximized the cladode length of $O$. stricta in $2.78 \mathrm{~cm}$.

Through the response surface generated for the cladode width is maximized in $10.55 \mathrm{~cm}$ at 150 days after planting when $57.79 \%$.ETc and $4.44 \mathrm{dS} / \mathrm{m}$ are used (Figure 6).

Amador et al. (2018) verified in O. ficus-indica that the cladode width is affected when salinity levels above $3 \mathrm{dS} / \mathrm{m}$ are used. Freire et al. (2018) verified an optimum level of $2.57 \mathrm{dS} / \mathrm{m}$ to maximize the cladode width of Little Sweet clone (N. cochenillifera) in $5.37 \mathrm{~cm}$. Queiroz et al. (2015) verified that when $0.0 \%$.ETc was used, maximized the cladode width of $O$. stricta in $2.46 \mathrm{~cm}$.
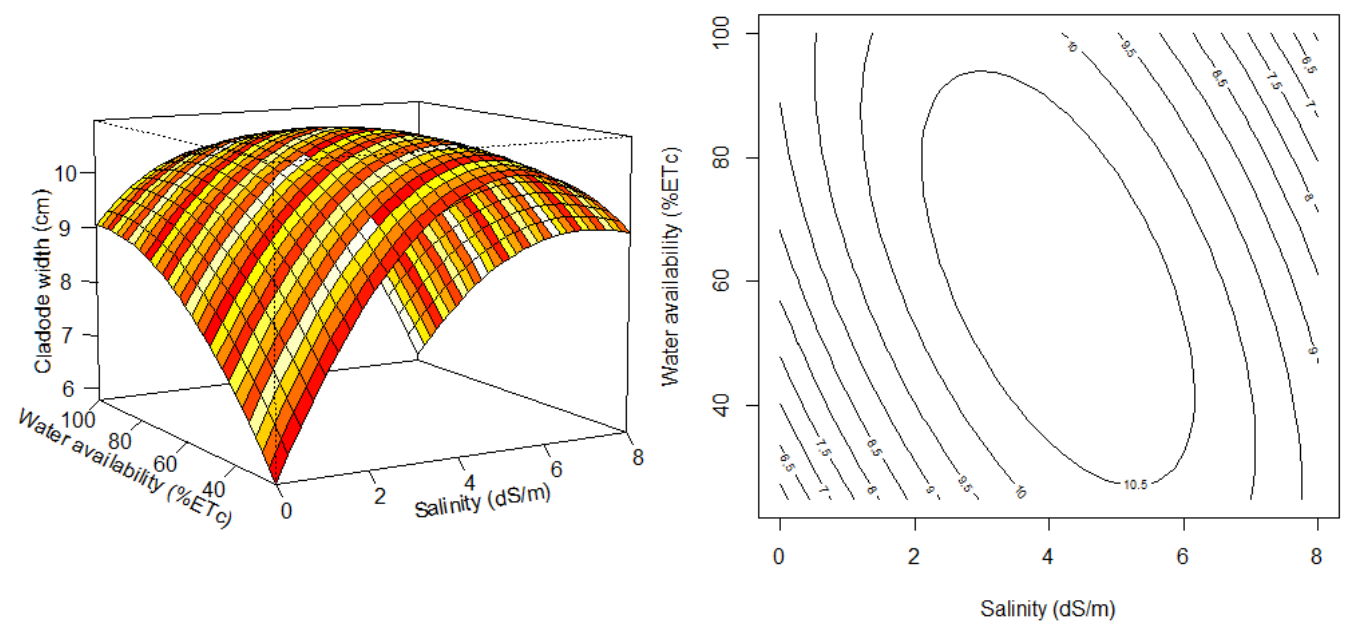

Figure 6 - Response surface of the cladode width of $N$. cochenillifera.
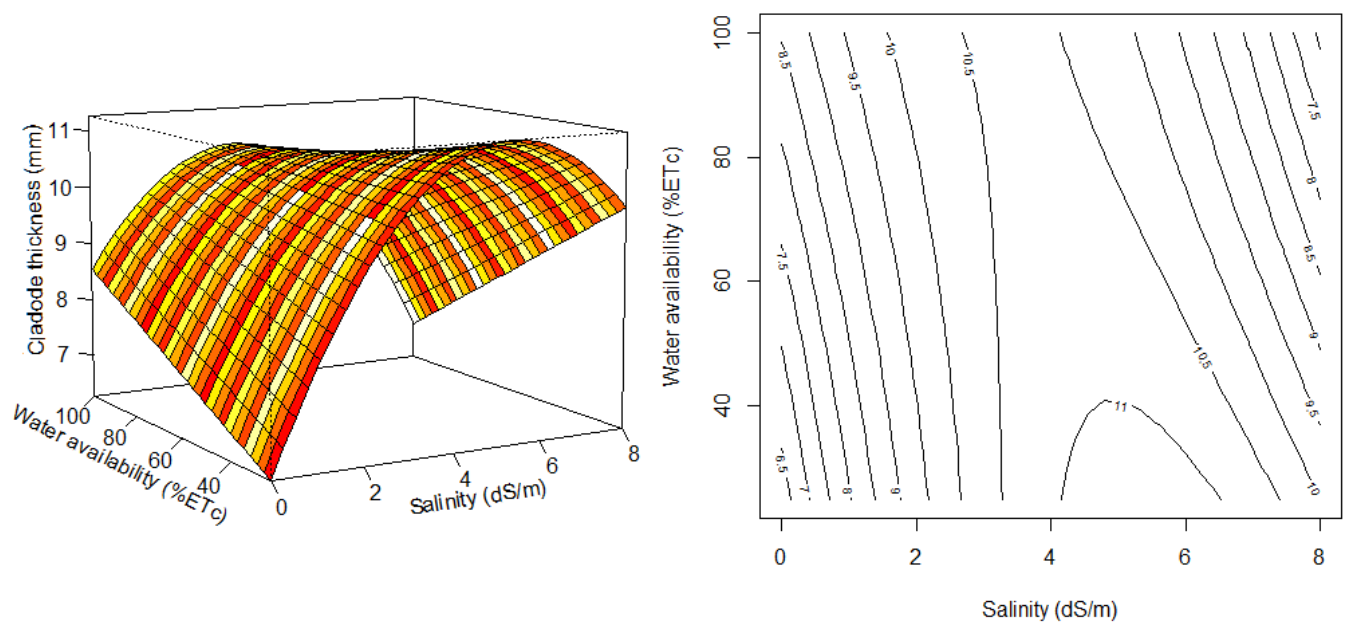

Figure 7 - Surface response of the cladode thickness of N. cochenillifera. 
Cladode thickness showed quadratic behavior as a function of crop evapotranspiration (\%ETc) and linear in relation to the salinity level, as well as interation between the two stresses (Table 3). Freire et al. (2018) observed that the cladode thickness of $N$. cochenillifera present linear behavior as a function of the salinity level at 21 days of experiment with $30.21 \%$ precision power.

Observed that the response surface for cladode thickness showed an optimal level of $56.89 \%$.ETc and $8.09 \mathrm{dS} / \mathrm{m}$ maximizing the thickness in $10.59 \mathrm{~mm}$ at 150 days after planting (Figure 7). Freire et al. (2018) maximized the thickness of Little Sweet clone ( $N$. cochenillifera) in $0.28 \mathrm{~cm}$ using a level of $3 \mathrm{dS} / \mathrm{m}$ of salinity. Queiroz et al. (2015) verified that when $0 \%$.ETc was used, maximized the cladode thickness of Opuntia stricta in $0.2 \mathrm{~cm}$.

\section{Conclusions}

Water and salt stresses interfere in the morphometric characteristics of the Giant Sweet clone in specie Nopalea cochenillifera, compromising the vegetative growth of the plant.

The crop evapotranspiration range between $55 \%$ and $65 \%$ promotes greater growth of the Giant Sweet clone, with greater plant height and greater cladode area, parameters related to photosynthetic efficiency and phytomass yield.

In the initial stage of development, this clone tolerates salinity levels of irrigation water of up to $5 \mathrm{dS} / \mathrm{m}$, without changing the morphological characteristics.

\section{Acknowledgements}

We would like to thank reviewers and editors for their comments and suggestions.

LUCENA, L. R. R., COSTA, A. C. L., OliveiRA, A. D. M., LEITE, M. L. M. V. Desenvolvimento inicial de cladódio clone Doce Gigante em função de estresse hídrico e salino. Rev. Bras. Biom. Lavras, v.39, n.2, p.279-292, 2021.

- RESUMO: As plantas forrageiras são consideradas um dos principais fatores para o desenvolvimento da pecuária em todo o mundo, por apresentarem alto potencial de produção de fitomassa, tolerância à seca, alto valor energético, grande reserva de água e fácil propagação. A palma forrageira destaca-se por apresentar tolerância ao déficit hídrico. Objetivou-se avaliar as características morfométricas de Nopalea cochenillifera clone Doce Gigante em função do estresse hídrico e salino. $O$ delineamento utilizado foi inteiramente casualizado em esquema fatorial 4x4, sendo composto de quarto níveis de reposição de água, com base na evapotranspiração da cultura (ETc): $25 \%$.ETc, 50\%.ETc, $75 \%$.ETc e 100\%.ETc e quatro níveis de salinidade da água $(0,2,4$ e $8 \mathrm{dS} / \mathrm{m})$, com quatro repetições, totalizando 64 unidades experimentais. Foram avaliadas as seguintes características morfométricas: Altura de planta, comprimento, largura, espessura, número de cladódios e área de cladódio. Foram realizadas oito avaliações durante o período experimental. Foi utilizada a análise de superfície de reposta para avaliar as características morfométricas dos cladódios. Os melhores níveis hídricos se deram entre 55 e 65.\%ETc e os salinos entre 3,5 e $5 \mathrm{dS} / \mathrm{m}$, maximizando as características morfométricas de clone Doce Gigante. 
- PALAVRAS-CHAVE: Características morfométricas; Nopalea cochenillifera; superfície de resposta.

\section{References}

ALMEIDA, M. C. R.; LEITE, M. L. M. V.; SÁ JR., E. H.; CRUZ, M. G.; MOURA, G. A.; MOURA, E. A.; SÁ, G. A. S.; LUCENA, L. R. R. Crescimento vegetativo de cultivares de milheto sob diferentes disponibilidades hídricas. Magistra, v.29, n.2, p.161$171,2017$.

AMADOR, B. M.; AVILA, A. C.; DIÉGUEZ, E. T.; GARIBAY, A. N.; JONES, H. G. Effects of $\mathrm{NaCl}$ salinity on growth and production of young cladodes of Opuntia ficusindica. Journal Agronomy \& Crop Science, v.187, n., p.269-279, 2018.

ARAÚJO, S. A. C.; VASQUEZ, H. M.; CAMPOSTRINI, E.; NETTO, A. T.; DEMINICIS, B. B.; LIMA É. S. Características fotossintéticas de genótipos de capimelefante anão (Pennisetum purpureum Schum.), em estresse hídrico. Acta Scientiarum: Animal Sciences, v.32, n.1, p.1-7, 2010.

ARAÚJO, J. R. G. N.; GOMES, F. T.; SILVA, M. J.; JARDIM, A. M. F. R.; SIMÕES, V. J. L. P.; IZIDRIO, J. L. P. S.; LEITE, M. L. M. V.; TEIXEIRA, V. I.; SILVA, T. G. F. Estresse hídrico em plantas forrageiras: Uma revisão. PUBVET, v.13, n.1, p.1-10, 2019.

BALARDIN, R. S.; SILVA, F. D. L.; DEBONA, D.; CORTE, G. D.; FAVERA, D. D.; TORMEN, N. R. Tratamento de sementes com fungicidas e inseticidas como redutores dos efeitos do estresse hídrico em plantas de soja. Ciência Rural, v.41, n.7, p.1120-1126, 2011.

BILIBIO, C.; CARVAlHO, J. A.; MARTINS, M.; REZENDE, F. C.; FREITAS, E. A.; GOMES, L. A. A. Desenvolvimento vegetativo e produtivo da berinjela submetida a diferentes tensões de água no solo. Revista Brasileira de Engenharia Agrícola $e$ Ambiental, v.14, n.7, p.730-735, 2010.

FREIRE, J. L.; SANTOS, M. V. F.; DUBEUX JR., J. C. B.; NETO, E. B.; LIRA, M. A.; CUNHA, M. V.; SANTOS, D. C.; AMORIM, S. O.; MELLO, A. C. L. Growth of cactus pear cv. Miúda under different salinity levels and irrigation frequencies. Anais da Academia Brasileira de Ciências, v.90, n.4, p.3893-3900, 2018.

GAJENDER; SINGH, G.; DAGAR, J. C.; LAL, K.; YADAV, R. K. Performance of edible cactus (Opuntia ficus-indica) in saline environments. Indian Journal of Agricultural Sciences, v.84, n.4, p.509-519, 2014.

LEITE, M.L.M.V.; SILVA, D. S.; ANDRADE, A. P.; PEREIRA, W. E.; RAMOS, J. P. F. Caracterização da produção de palma forrageira no Cariri paraibano. Revista Caatinga, v.27, n.2, p.192-200, 2014.

LEITE, M. L. M. V.; LUCENA, L. R. R.; SÁ JÚNIOR, E. H.; CRUZ, M. G. Estimativa da área foliar em Urochloa mosambicensis por dimensões lineares. Revista Agropecuária Técnica, v.38, n.1, p.9-16, 2017. 
LEITE, M. L. M. V.; LUCENA, L. R. R.; CRUZ, M. G.; SÁ JR., E. H.; SIMÕES, V. J. L. P. Leaf area estimate of Pennisetum glaucum by linear dimensions. Acta Scientiarum Animal Science, v.41, p.e42808, 2019.

LEITE, M. L. V.; LUCENA, L. R. R.; OLIVEIRA, A. D. M.; COSTA, A. C. L.; ANJOS, F. L. Q.; FARIAS, I. M.; SIMÕES, V. J. L. P.; ALMEIDA, M. C. R. Cladode area and weight of Nopalea cochenillifera clones as a function of morphometric characteristics. Journal of the Professional Association for Cactus Development, v.22, p.18-28, 2020.

LUCENA, L. R. R.; LEITE, M. L. M. V.; PEREIRA, J. S.; CAVALCANTE, A. B. Ajuste de curvas de crescimento do comprimento do cladódio de Nopalea cochenillifera. Biomatemática, v.26, p.39-52, 2016.

LUCENA, L. R. R.; LEITE, M. L. M. V.; SIMÕES, V. J. L. P.; SIMÕES, V. J. L. P.; ALMEIDA, M. C. R. Área de cladódio da palma Opuntia stricta utilizando dimensões lineares. Agrarian Academy, v.5, n.9, p.46-55, 2018.

LUCENA, L. R. R.; SIMÕES, J. V. L. P.; LEITE, M. L. M. V. Superfície de resposta de medidas morfométricas de Pennisetum glaucum submetidos ao estresse salino. Archivos de Zootecnia, v.68, n.264, p.540-545, 2019a.

LUCENA, L. R. R.; LEITE, M. L. M. V.; BORJA, C. R. S.; COSTA, A. C. L. Superfície de resposta no desenvolvimento do capim Pangolão submetidos a déficit hídrico e aplicação de bioestimulante. Biomatemática, v.29, n.1, p.17-34, $2019 \mathrm{~b}$.

LUCENA, L. R. R.; LEITE, M. L. M. V.; CRUZ JR., C. B.; CARVALHO, J. D.; SANTOS, E. R.; OLIVEIRA, A. D. M. Estimation of cladode area of Nopalea cochenillifera using digital images. Journal of the Professional Association for Cactus Development, v.21, p.32-42, 2019c.

MANGUEIRA, R. A. F.; SAVIAN, T. V.; MUNIZ, J. A.; SERMARINI, R. A.; CROSARIOL NETTO, J. O. Modelo logístico considerando diferentes distribuições para os erros aplicados a dados de altura do milho. Revista Brasileira de Biometria, v.34, n.2, p.317-333, 2016.

MUNNS, R.; TESTER, M. Mechanisms of Salinity Tolerance. Annual Review of Plant Biology, v.59, n.1, p.651-681, 2008.

PEREIRA, J. S.; LEITE, M. L. M. V.; CAVALCANTE, A. B.; LUCENA, L. R. R. Crescimento inicial de Nopalea cochenillifera em função do fracionamento do cladódio. Revista Agropecuária Técnica, v.39, n.2, p.120-128, 2018.

QUERIOZ, M. G.; SILVA, T. G. F.; ZOLNIER, S.; SILVA, S. M. S.; LIMA, L. R.; ALVES, J. O. Características morfofisiológicas e produtividade da palma forrageira em diferentes lâminas de irrigação. Revista Brasileira de Engenharia Agrícola e Ambiental, v.9, n.10, p.931-938, 2015.

R CORE TEAM. $R$ : a language and environment for statistical computing. Vienna: R Foundation for Statistical Computing, 2020.

SALAZAR, V. A. F.; VÉLIZ, J. A. Respuestas de la tuna [Opuntia ficus-indica (L.) Mill.] al NaCl. Interciencia, v.32, n.2, p.125-130, 2007. 
SILVA, J. R. I.; JARDIM, A. M. R. F.; NETO, J. B.; LEITE, M. L. M. V.; TEIXEIRA, V. I. Estresse salino como desafio para produção de plantas forrageiras. Pesquisa Aplicada \& Agrotecnologia, v.11, n.3, p.127-139, 2018.

Received on 15.03.2020

Approved after revised on 02.07.2020 